\title{
HAMLET NO CINEMA: AS ADAPTAÇÕES FÍLMICAS DE LAURENCE OLIVIER (1948) E FRANCO ZEFFIRELLI (1990)
}

\author{
Rogério Tomaz \\ FAE Centro Universitário \\ Universidade Federal do Paraná
}

\begin{abstract}
Resumo: As inter-relações entre as artes traduzem-se numa discussão bastante recente. Um dos elementos que compõem esse quadro é a tradução intersemiótica que consiste na relação entre sistemas signícos. Este artigo propõe a análise da abordagem intersemiótica na adaptação da peça de teatro Hamlet, Príncipe da Dinamarca, de William Shakespeare para o cinema nos filmes de Laurence Olivier e Franco Zeffirelli.
\end{abstract}

Palavras-chave: Dramaturgia. William Shakespeare. Hamlet. Cinema

"Certamente desde que Shakespeare surgiu no "teatro do globo", na sua dupla acepção, há tantos Shakespeares quantas as etapas e as transformações fundamentais do teatro e de suas correspondentes cosmovisões. Poder-se-ia até acrescentar que o seu número se multiplica pelo número de seus intérpretes mais significativos e renovadores.” Jacó Guinsburg ${ }^{1}$

\section{Prelúdio: o universo shakespeariano}

Por volta dos 18 anos, William Shakespeare abandona a pequena cidade de Stratfordupon-Avon e vai a Londres, onde inicia o vínculo com o teatro e, consequentemente, revela-se o maior dramaturgo de todos os tempos. A ele atribui-se a autoria de 37 peças que foram representadas e impressas sob seu nome, das quais se destacam Rei Lear, Hamlet, Otelo, A tempestade, A comédia dos erros, A megera domada e Macbeth.

\footnotetext{
${ }^{1}$ In HELIODORA, Bárbara. Falando de Shakespeare. São Paulo: Perspectiva, 1997.
} 
Se muito pouco se conhece sobre a biografia do autor inglês, muito se sabe sobre a obra do escritor e ator de teatro que viveu há séculos atrás e que, através de suas peças, arremeteu leitores das mais variadas épocas, perpetuando-se numa espécie de elo mágico que perdura e fascina homens e mulheres contemporâneos.

Shakespeare foi o pioneiro na análise da psique humana exteriorizada por personagens dotadas de introversão que escutam a si próprias e são capazes, por intermédio dos monólogos, de evoluir, enlouquecer ou, simplesmente, pensar. Há subversão dos valores vigentes, surge o questionamento das ações e dos comportamentos humanos e a semente do pensamento critico é lançada. O dramaturgo inglês impressiona por dizer coisas novas, por expressar os princípios dos tempos modernos na sociedade elisabetana. O misterioso Hamlet é um de seus porta-vozes.

Hamlet será o corpus de análise deste artigo. Porém, não se visa à observação comportamental das personagens, os recursos estilísticos utilizados por Shakespeare ou qualquer outro elemento literário presente na peça. O trabalho é resultado de um estudo interartes que contempla a tradução intersemiótica da tragédia Hamlet associada a duas adaptações fílmicas da obra: Hamlet, de Laurence Olivier, 1948, e Hamlet, de Franco Zeffirelli, 1990.

\section{O ler e o "dês-ler"}

Segundo Pavis, a adaptação é a "transposição ou transformação de uma obra, de um gênero em outro (de um romance numa peça, por exemplo)." Ainda de acordo com o escritor francês, a adaptação, também chamada de dramatização, apresenta como objeto os conteúdos narrativos que se mantêm, com maior ou menor grau de fidelidade, "enquanto a estrutura discursiva conhece uma transformação radical, principalmente pelo fato da passagem a um dispositivo de enunciação inteiramente diferente.” Assim, ao se deparar com o texto, escrito ou falado, o leitor apropria-se das ideias presentes no contexto verbal ou oral, criando uma relação de interatividade entre os polos.

Numa rápida passagem pelo campo da estética da recepção, verifica-se que no texto literário há uma série de indeterminações que possibilitam o início de uma maior interação entre o leitor e a obra. Esses "vazios" são os responsáveis pelas diferentes perspectivas de representação e estimulam o leitor a estabelecer conexões, coordenadas, entre os elementos do texto. A não presença de itens determináveis e apenas insinuados condiciona o

\footnotetext{
${ }^{2}$ PAVIS, Patrice. Dicionário de teatro. 3. ed. São Paulo: Perspectiva, 2008, p. 10.
} 
posicionamento do leitor na obra, como bem enuncia Jouve: "a ausência deliberada de uma anotação (um "vazio" na terminologia de Iser) é de fato um meio eficiente de programar a cooperação do leitor."3 Esses vazios provocam estímulos que impulsionam o receptor no preenchimento dos espaços existentes no texto, ou seja, obrigam-no a investir posições textuais precisas em que o texto controla a atividade. A indeterminação, a existência dos "vazios", é qualidade do texto e não figura como intenção do autor.

Umberto Eco afirma que o leitor mantém uma relação dialética com o autor da obra e, ao deparar-se com as indeterminações, exerceria a função de co-participante no processo de construção do texto.

O texto está, pois entremeado de espaços brancos, de interstícios a serem preenchidos, e que o emitiu previa que esses espaços e interstícios seriam preenchidos e os deixou branco por duas razões. Antes de tudo, porque um texto é um mecanismo preguiçoso (ou econômico) que vive da valorização de sentido que o destinatário ali introduziu [...] Em segundo lugar, porque à medida que passa da função didática para a estética, o texto quer deixar ao leitor a iniciativa interpretativa, embora costume ser interpretado com uma margem de univocidade. Todo texto quer alguém que o ajude funcionar. ${ }^{4}$

Eco apresenta os movimentos cooperativos realizados pelo leitor no processo de leitura. A priori, o leitor se depara com a linearidade do texto que deve possuir uma língua comum ao emissor e ao destinatário. Em um segundo momento, há a identificação do contexto linguístico e das circunstâncias de enunciação. De acordo com o autor, ainda, o leitor, ao iniciar o ato de ler, recorre a sua "enciclopédia" que se configura como uma espécie de biblioteca mental, englobando todos os registros de interpretações anteriores (linguagem literária, oralidade, universo fílmico e expressões artísticas em geral).

Portanto, para o escritor italiano, a obra literária apresenta, essencialmente, caráter de abertura, estabelecendo diálogo entre o leitor, o mundo e outras obras literárias ou artísticas. Essa relação que todo texto tem com seu intertexto, nas palavras de Hutcheon ${ }^{5}$, chama-se "intertextualidade" e é responsável pelas assimilações e as transformações dos textos, ou seja, tem-se o princípio de que ninguém faz ou cria uma obra artística ou literária do nada, sempre haverá a retomada de alguma ideia já existente. Avulta-se numa espécie de conversa estabelecida entre os livros. Nas palavras de Focault:

As fronteiras de um livro nunca são bem definidas: por trás de um título, das primeiras linhas e do último ponto final, por trás de sua configuração interna e de

\footnotetext{
${ }^{3}$ JOUVE, Vicente. A leitura. São Paulo: Ed. UNESP, 2002, p. 72.

${ }^{4}$ ECO, Umberto. Lector in fabula: a cooperação interpretativa nos textos narrativos. São Paulo: Perspectiva, 1986, p. 37.

${ }^{5}$ HUTCHEON, Linda. Poética do pós-modernismo: história, ficção. Rio de Janeiro: Imago, 1991, p. 09.
} 
sua forma autônoma, ele fica preso num sistema de referências a outros livros, outros textos, outras frases: é um nó dentro de uma rede. ${ }^{6}$

Para Kristeva (1974, p. 64), a compreensão do fenômeno da intertextualidade origina-se nos estudos de Mikhail Bakhtin, pioneiro ao afirmar que a estrutura literária é elaborada a partir de sua relação com outra estrutura, processo denominado pelo escritor russo de polifonia. De acordo com a autora búlgara, todo texto é construído como um mosaico de citações que absorve e transforma o texto anterior, estendendo significativamente a noção de texto.

Nesse contexto, a apropriação textual torna-se nata à obra, sendo ela consequência da conexão estabelecida com o leitor. Em outras palavras, sempre que o leitor encontrar com o texto e com ele interagir, na qualidade de receptor, transformará a realidade em nova obra literária ou artística, reforçando a sobrevivência dos clássicos e de todas as obras que a elas estejam atreladas. A intertextualidade substitui, portanto, o relacionamento autor-texto. Caminha-se para a questão da originalidade textual.

No artigo A representação dos clássicos: reescritura ou museu, Anne Ubersfeld (2002) apresenta a discussão do que pode ser considerado clássico. Logo no início do trabalho, a autora francesa afirma que, de modo geral, considera-se "clássico tudo aquilo que, não tendo sido escrito para nós mas para outros, reclama uma "adaptação" a nossos ouvidos."7 A adaptação, neste sentido, refere-se a algo inserido em novo contexto: "ler hoje é dês-ler o que foi lido ontem." A afirmação da pioneira nos estudos teatrais originados do estruturalismo é fundamental quando se pensa na adaptação de obras literárias ou artísticas ao presente. Segundo a autora, as mudanças ocasionadas no campo das ciências humanas revelam que a obra clássica não pode ser compreendida apenas como um objeto sagrado, “depositário de um sentido oculto, como o ídolo no interior de um templo." ${ }^{8}$ Deve-se encarála como a mensagem de um processo de comunicação em que a releitura do passado visa à apresentação da leitura do presente.

Em O prazer do texto, Barthes (1996) apregoava que a produção textual do presente mantém uma relação dialógica, de reciprocidade com o passado e com o futuro, resultando numa forma de entrelaçamento textual infinito. O autor contesta, ainda, a noção de originalidade e autoridade autoral ao afirmar que fornecer "ao texto um autor é impor-lhe um

\footnotetext{
${ }^{6}$ FOCAULT, Michel apud HUTCHEON, Op. Cit., p. 167.

${ }^{7}$ UBERSFELD, Anne. A representação dos clássicos: reescritura ou museu. In SAADI, Fátima. (ed.) Folhetim: teatro do pequeno gesto. n. ${ }^{\circ}$ 13. Rio de Janeiro, Prefeitura da Cidade do Rio de Janeiro, Secretarias de Cultura, Rio Arte, abr-jun 2002, p. 09.

${ }^{8}$ UBERSFELD, Op. Cit., p. 12.
} 
travão, é provê-lo de um significado último, é fechar a escritura." ${ }^{9}$ Nesta concepção, o texto compõe-se de escritas múltiplas, provenientes de culturas diversas, que dialogam entre si, em paródia ou em oposição umas com as outras. O leitor define-se como a entidade capaz de perceber a duplicidade e multiplicidade dos textos, o que reforça a relação leitor-texto, apresentada anteriormente.

Os pressupostos teóricos elucidados até o momento auxiliam no entendimento de que a origem de toda arte encontra-se sempre na arte precedente: há uma reavaliação da literatura do passado para a existência da nova. As palavras de Plaza traduzem com precisão este pensamento:

\begin{abstract}
A tradução entre as diversas artes tem, na visão sincrônica da história, a forma mais adequada e consubstancial a seu projeto. A relação passado-presente constitui-se na realidade em dois polos dialéticos cuja conjunção como opostos é necessária, uma vez que eles se apresentam em qualquer projeto poético: mesmo quando a nega, a origem de toda arte encontra-se sempre na arte precedente. Ao artista aprende (e ensina) do artista. Na tradução, entretanto, essa característica se acentua. O espaçotempo da tradução é o da coincidência e da sincronia entre passado e presente, o da ressonância entre formas artísticas. ${ }^{10}$
\end{abstract}

O leitor nunca será sujeito passivo no processo de recepção, pois ao entrar no universo do texto, ele inicia a construção semântica de acordo com o histórico de leitura que possui. Recorrendo às palavras de Eco, ativa a "enciclopédia". Para Pavis (2008), quando o leitor-intencionado inicia a absorção dos significados, interseccionando o texto fonte à nova visão do texto almejado, incide no fenômeno da "historização". Este ponto de intersecção torna-se importante, pois é através dele que as ideias se concatenarão e novas obras serão produzidas. $\mathrm{O}$ receptor age num processo de construir e reconstruir o texto, em que o produto da recriação é maior que o objeto-fonte.

$\mathrm{Na}$ introdução do livro The appropriation of Shakeaspeare: post-renaissance reconstruction of the works and the myth, Marsden ${ }^{11}$ cita o posicionamento de Jauss para afirmar que a obra literária não é um monumento que revela monologicamente sua essência atemporal. Ou seja, o autor enfatiza que a continuidade de uma obra reside no potencial que esta possui de influenciar e ser influenciada, fazendo clara alusão à necessidade dos homens de produzir mitos e, uma vez estabelecidos, manipulá-los. Este fato justificaria a motivação de dramaturgos e diretores de peças teatrais de "apoderar-se" de uma obra do passado e de tentarem atualizá-la, trazendo-a para a contemporaneidade. É válido lembrar que o campo dos

\footnotetext{
${ }^{9}$ BARTHES, Roland. O prazer do texto. 4. ed. São Paulo: Perspectiva, 1996.

${ }^{10}$ PLAZA, Júlio. Tradução intersemiótica. São Paulo: Perspectiva, 2003, p. 205.

${ }^{11}$ MARSDEN, Jean. The appropriation of Shakeaspeare: post-renaissance reconstruction of the works and the myth. New York: Harvester Wheatsheaf, 1991, p. 09.
} 
estudos literários torna-se propício à apropriação textual, revelando-se de forma necessária e inevitável. É através do apropriar-se literariamente que a obra torna-se propriedade alheia, garantindo-lhe a existência por intermédio da reinvenção.

Nem sempre a apropriação artística é vista com bons olhos pela crítica tradicional. Para alguns, ao realizar a montagem, o chamado remake de algum clássico, deve-se atentar à questão da fidelidade, ou seja, quanto maior a aproximação com o "original”, melhor será a qualidade do resultado. Romeu e Julieta, adaptação fílmica de Baz Luhrman, de 1996, recebeu severas críticas dos puristas por apresentar uma tradução intersemiótica e cultural diversa da ambientada aos moldes shakespearianos.

Contudo, as ideias de fidelidade estão superadas. O processo de construção artística como fruto do criar único não é mais concebido na totalidade, ele vai além, quebra as barreiras do que é dito “original". Sim, pois os clássicos, os cânones não são tão pioneiros quanto se imagina que sejam.

\section{Hamlet e o cinema}

Hamlet, Príncipe da Dinamarca, célebre peça shakespeariana escrita, provavelmente, em meados de 1600, e encenada pela primeira vez no Globe Theatre, em 1601, é seguramente a tragédia do autor inglês mais representada em todos os tempos. Mourthé afirma:

\footnotetext{
Hamlet inaugura assim, no zênite da carreira de Shakespeare e no momento em que vai começar a dos Stuart, o ciclo do que foi chamado de dark plays, as peças com problemas, O rei Lear e Macbeth vindo a seguir. [...] Nenhuma peça de teatro, nenhuma obra escrita suscitarão tantos comentários, tantas exegeses, tantas interpretações. $^{12}$
}

Nem mesmo o imortal autor inglês fugiu à regra do "dês-ler o que foi lido ontem". Para criar o clássico Hamlet, Príncipe da Dinamarca, o autor inglês inspirou-se na crônica dinamarquesa de Saxo Grammaticus, Gesta Danorum, escrita em 1514, alterando alguns aspectos do enredo e os nomes originais das personagens. Cláudio representa Fergon, o rei homicida que mata o irmão para ficar com o trono e a cunhada; Horwendil, o fantasma do rei morto, virou o pai de Hamlet; a rainha Gerutha tornou-se Gertudres e Amleth, o filho vingador, uma das personagens mais conhecidas de Shakespeare: Hamlet.

Acredita-se, ainda, que a tragédia que tinha como cenário o Castelo de Elsenor, na Dinamarca, era muito conhecida entre os escandinavos, existindo várias lendas que derivavam

\footnotetext{
${ }^{12}$ MOURTHÉ, Claude. Shakespeare. Porto Alegre: L\&PM, 2007, p. 140.
} 
dela. Crê-se que mesmo na época de Shakespeare havia uma versão alemã da tragédia sendo encenada na Europa.

Quando se deixa a época de ouro do teatro elisabetano e dirige-se ao mundo das interartes do século XXI, como fica a história do Príncipe Dinamarquês? A resposta surge da própria desmistificação da ideia de originalidade expressas nas palavras de Guinsburg que compunham a epígrafe exposta no início deste trabalho: "há tantos "Hamlets" quanto às etapas e as transformações fundamentais do teatro e de suas correspondentes cosmovisões."

No cinema, espaço para a projeção das emoções humanas fora do "real", as adaptações da tragédia shakespeariana ganharam muito espaço. Diversos escritores e pensadores nestes últimos quatro séculos deixaram impressões sobre o impacto que lhes causou a história do príncipe infeliz. No cinema, já foram realizadas mais de 70 adaptações de Hamlet. Adentra-se neste momento à análise de duas adaptações de Hamlet, separadas por um lapso temporal de 42 anos e produzidas em momentos ímpares da trajetória da sétima arte. As rápidas considerações sobre a vida dos dois cineastas que produziram os filmes aqui abordados são necessárias para que o leitor se situe em relação aos filmes que serão apresentados neste estudo.

Laurence Kerr Olivier nasceu em Dorking, na Inglaterra. Aos 17 anos abandonou a universidade e começou a se empenhar nas artes dramáticas. Estreou na Broadway e em Hollywood, onde atuou em papeis de não destaque. Olivier ganhou fama nos palcos interpretando personagens de Shakespeare. Aos 30 anos foi considerado o maior ator shakespeariano de sua geração. Foi convidado a voltar a Hollywood, onde fez sucessivos filmes de sucesso, incluindo Hamlet que foi lançado nos Estados Unidos em 1948.

Franco Zeffirelli, nome artístico de Gianfranco Corsi, nasceu em Florença, na Itália, em 12 de fevereiro de 1923. É um renomado cineasta italiano, sendo, também, cenógrafo e diretor de teatro, ofício no qual alcançou sucesso nos anos cinquenta, montando óperas líricas. Zeffirelli é reconhecido como diretor teatral e trabalhou em muitos dos melhores teatros do mundo, inclusive no Metropolitan Opera of New York e no Convent Garden de Londres. A versão "zeffirilliana” de Hamlet foi lançada, também, nos Estados Unidos, em 1990.

A fuga ou a distorção do cânone, do clássico nas palavras de Ubersfeld, é, geralmente, vista com maus olhos pela crítica tradicionalista. Assim, o produto da adaptação tende a ser descartado ou não recebe o devido valor. Os trabalhos de tradução intersemiótica realizados por Olivier e Zeffirelli contemplam, num primeiro plano, as ideias desse segmento, ou seja, enquadram-se no modelo esperado pelo universo crítico. Fato que pode ser justificado 
pela aproximação do roteiro à tragédia shakespeariana. Porém, isso não significa que traduzem com fidelidade o texto fonte.

Um ponto comum entre as duas versões cinematográficas de Hamlet é a qualificação enquanto gênero: o drama. Ambos contam histórias centradas em conflitos individuais, no caso, a vingança do protagonista ao assassino do pai, provocados por problemas existenciais, representados, neste caso, pelo célebre to be or not to be, that's the question. Há constantemente uma situação de tensão inserida na peça, a qual se estende até o clímax, o duelo com Laertes, em que o equilíbrio é reconstituído, embora o final não seja feliz. Para os críticos cinéfilos, o drama busca provocar intensas reações emocionais, mas se o objetivo maior for o sucesso comercial do filme, o final deve ser feliz. Shakespeare não é comércio, é arte.

A análise minuciosa das produções em questão requer a lembrança de que o diretor é, no trabalho de adaptação, antes de tudo um leitor. Nesse processo dinâmico do apropriar-se, o ato de recriar é maior que a própria fonte, o que leva a resultados diferenciados para obras de igual conteúdo.

O cineasta e ator inglês Laurence Olivier adaptou diversas peças de Shakespeare para as telas de cinema, mas foi com a história de Hamlet que ele se tornou conhecido e consagrado. Essa adaptação constituiu-se na primeira versão sonora da clássica história de William Shakespeare.

Ao observar a primeira cena de Hamlet de Laurence Olivier, percebe-se o anúncio do trágico. Horácio, amigo de Hamlet, e alguns soldados da corte dinamarquesa encontram-se na torre do castelo, parados, com uma maca sobre os ombros e um corpo nela estendido. $\mathrm{O}$ receptor, ou melhor, o expectador logo imaginará que o cadáver seja do próprio Hamlet. A suspeita é confirmada e o enigma desfeito quando o protagonista narra seu destino: Esta é a tragédia de um homem que não podia tomar uma decisão.

Na versão de Franco Zeffirelli, no início do filme, o expectador depara-se com a cena em que o corpo do rei está sendo velado. Nesse plano, a Rainha Gertrudes chora a morte do esposo e Hamlet é apresentado ao público com ares de ansiedade, numa espécie de premonição do trágico futuro.

Em Shakespeare, na plataforma do Castelo de Elsinore, Bernardo e Marcelo, oficiais do rei, cuidam da guarda e em conversa com Horácio, amigo de Hamlet, relatam a aparição de um fantasma. Horácio não acredita na história dos oficiais, o espectro surge e a peça inicia.

A cena de abertura da tragédia shakespeariana é retomada de diferentes formas nas adaptações de Olivier e Zeffirelli. Cada diretor escolheu um canal, um viés, fruto da 
compreensão de leitura que realizou da obra de William Shakespeare. Ou ainda, retomando Pavis (2008), o leitor-intencionado intersecciona o texto de origem ao texto que deseja criar, incidindo no fenômeno da historicização. Introduzido por Brecht, historicizar consiste em revelar um acontecimento ou uma personagem à sua luz social, histórica, relativa e transformável. Nas palavras do dramaturgo alemão, é "mostrar os acontecimentos e os homens sob seu aspecto histórico, efêmero." 13

A adaptação fílmica de Laurence Olivier apresenta uma série de recursos que merecem destaque. O movimento da câmera, por exemplo, é utilizado para a apresentação de novos cenários e para as passagens de cena. $\mathrm{O}$ cineasta usou, também, o recurso da tela negra, em que a imagem desaparece e o expectador a vê escurecida por frações de segundo. Quando ela reaparece, tem-se um novo cenário, funcionando como uma cortina de teatro.

Os cenários e a fotografia do filme são bastante artesanais. Contudo, antes de abordar qualquer assunto neste sentido, torna-se necessário lembrar de que a reconstrução histórica feita nesses moldes é justificada quando se pensa no ano de lançamento, 1948, época em que os recursos e as verbas destinadas aos filmes eram limitados. Assim, é possível perceber pinturas de fundo que revelam nuvens, montanhas, árvores, etc., num processo de reconstituição artesanal da Dinamarca. Os ambientes são, geralmente, escuros, úmidos e frios, interligados por corredores e escadarias que passam ao expectador a imagem de um teatro filmado. Muitas cenas privilegiam objetos estáticos e parados, ideias estas acentuadas quando se releva a cor da película da produção: preto e branco.

Outra forte característica dessa produção fílmica é a já anunciada semelhança com o teatro. No início do filme, o expectador acredita estar assistindo à apresentação teatral. Entretanto, gradativamente, essa ideia é desmistificada e sutis mudanças são reveladas acentuando as diferenças entre os dois universos. O cinema possibilitou ao diretor Laurence Olivier o estabelecimento de um jogo com os pensamentos, em que as principais falas da trama ganharam a possibilidade do pensamento audível. Em outras palavras, o que na dramaturgia era parte da fala direta dos atores, na produção fílmica são falas em off das personagens que possibilita ao expectador o "ouvir" pensamentos.

Olivier fez, ainda, grandes cortes na peça original, limitando-se a por em cena o material dramático relacionado à família real da Dinamarca e às devidas experiências e alterações psíquicas dela. Não há preocupação com o enquadramento histórico e os conflitos

\footnotetext{
${ }^{13}$ BRECHT, 1967 apud PAVIS, 2008, p. 196.
} 
políticos com a Noruega. O texto, o roteiro, sobrepõe-se às demais ações e concerne ao filme caráter contemplativo, mental e filosófico.

Ao falar em filosofia, não se pode deixar de lado a célebre cena da tragédia shakespeariana: o ser ou não ser. Em Olivier, após discutir com Ofélia e afirmar que não a quer como esposa, Hamlet sobe as escadas e caminha para o topo da torre do Castelo de Elsinore, movimento que sugere à ascensão ao céu, a busca das respostas para as dúvidas num plano superior, divino. Coloca-se em xeque a existência do ser humano. Em Shakespeare, o homem constrói seu destino e o seu roteiro de vida será determinado pelos traços de caráter, como a bondade, a maldade, a inveja e os demais sentimentos. Não existe nenhuma outra força alheia direcionando alguém para a tragédia a não ser a própria vontade.

A crítica observou como ponto negativo da adaptação a redução do texto shakespeariano. Porém, esse fato não impediu que o filme recebesse 4 estatuetas do Oscar, nas categorias de: melhor filme, melhor ator (Laurence Olivier), melhor direção de arte e melhor figurino. Além disso, foi indicado nas categorias de melhor diretor, melhor atriz coadjuvante (Jean Simmons) e melhor trilha sonora. Recebeu os Globos de Ouro de melhor filme estrangeiro e melhor ator; e ganhou o Leão de Ouro no Festival de Veneza.

A pluralidade de visões derivadas da capacidade interpretativa de cada receptor, expectador ou leitor é a responsável pelas diversas formas de representação de uma obra. Olivier escolheu um ramo de abordagem para Hamlet diferente do resultado encontrado e proposto por Franco Zeffirelli que não quis dar um clima negro, tão trágico e complexo à obra de William Shakespeare.

O cineasta italiano, junto com a equipe técnica, realizou um primoroso trabalho de reconstrução histórica e cenográfica para ambientar a história de Hamlet, Príncipe da Dinamarca. A preferência por uma versão mais amena e simples envolveria uma série de elementos, em que o uso dos espaços internos e externos exerceria papel de fundamental importância. Os profissionais envolvidos no trabalho encontraram na Escócia um castelo que se enquadrava aos moldes do que se imaginava o Elsinore. Escolhia-se, assim, o novo set de filmagens para ambientes externos. Para as cenas gravadas no interior do reinado, recorreu-se à montagem de um estúdio na cidade de Londres.

O resultado dessa reconstituição foram cenas verossímeis que fugiam da penumbra e da frieza encontradas nos cenários de Olivier. Nesse sentido, com a ajuda da fotografia, o expectador tem a nítida sensação de estar vivenciando o cenário da época.

Pode-se afirmar que Franco Zeffirelli buscou inspiração no filme de Laurence Olivier, pois, afinal, segundo Plaza (2003), a origem de toda arte encontra-se sempre na arte 
precedente. Ele trouxe o palco às telas, não como seu precursor o fez, mas de uma maneira em que os recursos cinematográficos se acentuaram.

$\mathrm{Na}$ cena do famoso solilóquio de Hamlet, o cineasta italiano não busca as respostas no interior do homem. Ele faz analogia a Olivier. Porém, se para este, Hamlet busca as respostas no céu, através de um ser supremo, para aquele, o protagonista vai descer às profundezas, no caso, uma caverna, um porão ou uma catacumba para encontrar as respostas das dúvidas que cercam a existência humana. Elas não pertencem a um ser supremo ou se pertencem, não chegarão aos humanos, pois elas apenas levam ao fundo do poço.

Ao contrário das outras versões, a tradução intersemiótica de Zeffirelli mostra o lado mais emotivo, mais sombrio e humano de Hamlet. A crítica consolida-a como uma história jovial. Não poderia ser diferente, pois a produção fílmica foi ambientada na década de 90, ápice da produção hollywoodiana, e dos elementos tecnológicos que poderiam transformá-la numa grande produção.

Interessante, ainda, é perceber como o enfoque dado às personagens shakespearianas recebe tratamento diferenciado nas duas versões aqui elucidadas. O fantasma do rei assassinado aparece, em Olivier, como elemento sobrenatural, sombrio, cercado de fumaça e muito mistério. Em Zeffirelli, o pai de Hamlet aproxima-se mais do humano e abandona a forma de espectro, fala estritamente o necessário pedindo ao filho que vingue sua morte.

Na produção de 1948, o protagonista Hamlet sofre intensamente, o tempo todo. Não há motivos para felicidade, a angústia e a mágoa parecem sufocá-lo. Vínculos afetivos deixam de existir em nome da vingança do pai: não há ligação a nenhuma outra pessoa, nem à mãe, nem a Horácio ou à Ofélia, pois há contas a acertar apenas consigo e com sua consciência. $\mathrm{O}$ Hamlet dos anos 90 é despojado, jovem, hollywoodiano, criticado por apresentar traços de modernidade.

Personagem curiosa é a Rainha Gertrudes. No filme de Olivier, a mãe de Hamlet faz parte do núcleo de ação, mas não se destaca como personagem, é apenas vítima do destino. Já em Zeffirelli, a atuação da Rainha ganha voz e ação, tornando-a peça fundamental no processo de introspecção de Hamlet. Isso pode ser compreendido pela atuação das atrizes escolhidas para vivenciar cada uma das personagens. No caso de Ofélia, a amada de Hamlet acontece o contrário, na produção de Olivier, encontra-se uma jovem apaixonada, sofredora por não ser correspondida amorosamente. Em Zeffirelli, isso ocorre de forma mais tênue. 


\section{Considerações finais}

O arcabouço teórico e a análise substancial das adaptações fílmicas de Laurence Olivier e Franco Zeffirelli inserem-se na pluralidade de interpretações concedidas através do universo shakespeariano aos novos emissores. Nesse mundo, as possibilidades são oriundas da pós-modernidade, responsável por fornecer aos leitores o sincronismo no ato de ler, possibilitando a realização de adaptações e a releitura dos clássicos, do que foi lido ontem.

O modernismo caracterizou-se, principalmente, pela ruptura com os elementos consagrados pela tradição. Em contrapartida, a pós-modernidade retomou o que havia sido deixado de lado por este movimento. O resultado do processo foi o híbrido, o não homogêneo, mundo de misturas que se tornou reflexo da contemporaneidade.

Nessa imagem pós-moderna da realidade, a criação está drasticamente influenciada pelos meios de repro-produção de linguagens. O fenômeno de repro-produzir incide no meio das interartes, referindo-se às varias facetas dos meios eletrônicos. Assim, é possível transformar, por exemplo, a literatura em cinema.

A obra literária sempre manteve papel de destaque no processo de transmissão do signo. Porém, a relação entre as duas formas de expressão artística, cinema e literatura, só é possível através da interdependência entre os dois sistemas, havendo influência de um sobre o outro. Cada arte possui seu signo, seu diferencial.

O cinema possibilita ao adaptador o trabalho com a fotografia e seus múltiplos recursos, em que é possível reconstruir uma história sob diversos prismas. A arte não imita a vida, mas a recria, possibilitando um outro lugar do real.

Durante muito tempo acreditou-se que quanto mais fiel a adaptação fosse ao clássico, maior seria a qualidade do produto. Dessa forma, um bom trabalho estaria associado à fidelidade ao texto fonte. Porém, conforme anunciado em momento anterior, esta questão está superada. A obra de arte não pode ser considerada original. Ao criá-la, o artista recorre às suas experiências, as suas leituras, à sua enciclopédia, elementos que traduzem a intertextualidade.

A construção e a reconstrução descartaram o impasse sobre a originalidade e a fidelidade. Há de se entender que cada emissor é um potencial criador e cada escritor cria seus próprios precursores. O processo de apropriação não envolve somente a releitura, deve-se recriar, fazendo com que a novidade seja melhor do que a repetição. É a adaptação como o novo.

A crítica sempre se preocupou com o grau de "lealdade" ao texto fonte, ao clássico. Contudo, as ideias da estética da recepção desmistificaram esses paradigmas. Os leitores 
abandonaram a passividade no processo de leitura e passaram a interagir com o texto, tornando-se co-autores, uma vez que é permitida a expressão de sentimentos, a retomada, a criação do novo, a recriação.

No processo da recriação literária para o cinema, a crítica contemporânea traz um novo enfoque ao dar ênfase na comparação entre os dois meios objetivando enriquecer a avaliação do filme e não o contrário. O livro literário é valido por si só, sobrevive por ele mesmo.

A crítica passou a basear-se na espécie de adaptação pela qual o filme se propôs a ser e não na separação de que existe apenas uma maneira de adaptar uma obra literária. É o que Brian McFarlane ${ }^{14}$ chamou de adaptation proper ou adaptação criativa, processo de transferência que exige maior criatividade do cineasta.

O texto fonte deve estar por trás da nova obra, da obra moderna, mesmo que seja para apresentá-la.

As obras, as peças teatrais de William Shakespeare fizeram e ainda fazem sucesso, pois tratam de temas próprios dos seres humanos, independente do tempo histórico. Amor, relacionamentos conflituosos, sentimentos, questões sociais, temas políticos e outros assuntos relacionados à condição humana são constantes nas obras do escritor inglês. Shakespeare conhece o homem. Shakespeare sobrevive através das retomadas, das adaptações e das traduções intersemióticas, pois a boa obra nunca deve estar concluída. O artista torna-se vivo desde que consiga estipular dialogo entre os tempos.

Shakespeare não é cânone simplesmente. É fruto da tradição que dialoga com o presente e está pronto para ser retomado na formulação de um novo significado.

\section{Referências}

BARTHES, Roland. O prazer do texto. Trad. J. Guinsburg. 4. ed. São Paulo: Perspectiva, 1996.

CLÜVER, Claus. Estudos interartes: conceitos, termos, objetivos. In: Literatura e sociedade 2: revista de teoria literária e literatura comparada. São Paulo: Universidade de São Paulo, 1997.

ECO, Umberto. Lector in fabula: a cooperação interpretativa nos textos narrativos. São Paulo: Perspectiva, 1986.

${ }^{14}$ McFARLANE, Brian. Novel to Film: an introduction to the Theory of Adaptation. Oxford: Clarendon Press, 1996. 
ELIOT, T. S. Ensaios. Trad. Ivan Junqueira. Rio de Janeiro: Art Editora, 1989.

HAMLET. Direção de Franco Zeffirelli. Estados Unidos: Warner Bross Pictures: Columbia Pictures, 1990. 1 filme (130 min), sonoro, legenda, color.

HAMLET. Direção de Laurence Olivier. Inglaterra: Two Cities Films Ltd.: LW Editora, 1948. 1 filme (155 min), sonoro, legenda, $\mathrm{p} \& \mathrm{~b}$.

HELIODORA, Bárbara. Falando de Shakespeare. São Paulo: Perspectiva, 1997.

HUTCHEON, Linda. Poética do pós-modernismo: história, teoria, ficção. Trad. Ricardo Cruz. Rio de Janeiro: Imago, 1991.

JOUVE, Vincent. A leitura. São Paulo: Ed. UNESP, 2002.

KRISTEVA, Julia. Introdução à Semanálise. São Paulo: Perspectiva, 1974.

MARSDEN, Jean. The appropriation of Shakeaspeare: post-renaissance reconstruction of the works and the myth. New York: Harvester Wheatsheaf, 1991.

McFARLANE, Brian. Novel to Film: an introduction to the Theory of Adaptation. Oxford: Clarendon Press, 1996.

MOURTHÉ, Claude. Shakespeare. Trad. Paulo Neves. Porto Alegre: L\&PM, 2007.

PAVIS, Patrice. Dicionário de Teatro. Trad. J. Guinsburg e Maria Lúcia Pereira. 3. ed. São Paulo: Perspectiva, 2008.

PLAZA, Julio. Tradução intersemiótica. São Paulo: Perspectiva, 2003.

SHAKESPEARE, William. Hamlet; Macbeth; tradução de Hamlet [por] Anna Amélia Carneiro de Mendonça, tradução de Macbeth [por] Barbara Heliodora. Rio de Janeiro: Nova Fronteira, 1995.

UBERSFELD, Anne. A representação dos clássicos: reescritura ou museu. In: SAADI, Fátima. (ed.) Folhetim: teatro do pequeno gesto. n. ${ }^{\circ} 13$. Rio de Janeiro, Prefeitura da Cidade do Rio de Janeiro, Secretarias de Cultura, Rio Arte, abr-jun 2002.

[Recebido em agosto de 2011 e aceito para publicação em outubro de 2011]

Hamlet in cinema: the cinematic adaptations of Laurence Olivier (1948) and Franco Zeffirelli (1990)

Abstract: The inter-relations between the arts translate into a fairly recent discussion. One of the elements of this framework is the translation intersemiotic that consists of the connection between signal systems. This article proposes the analysis of the intersemiotic adaptation of the play Hamlet, Prince of Denmark, by William Shakespeare for the cinema in films of Laurence Olivier and Franco Zeffirelli. 
Keywords: Dramaturgy. William Shakespeare. Hamlet. Cinema

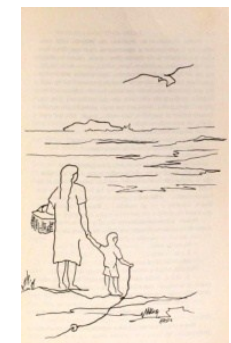

